\title{
The Scientific Research of Rehabilitation Training Program Participants in Stroke Patients
}

Young Wan Jin*

\section{Department of Special Physical Education, Dong-Eui University, Busan 614-714, Korea}

Received September 20, 2010 /Accepted November 17, 2010

\begin{abstract}
The purpose of this study was to describe the biomechanical characteristics of stroke patients. These characteristics were obtained during walking on a Zebris system, cinematography system and EMG system. Seven female stroke patients participated in this study. The magnitude of the profiles (joint peak angle, joint peak moments, foot pressure COP, EMG data) correlated with rehabilitation training duration using t-test. The significance level selected for this study was $p<0.05$, t-test. Joint analysis identified significant differences in hip joint peak angle and hip joint peak moment. Foot pressure verified significant differences in gait line length of COP. The EMG signal proved significant differences in rectus femoris and vastus lateralis.
\end{abstract}

Key words : Stroke patients, rehabilitation program, joint angle \& moment, COP, EMG signal

\section{서 론}

인구의 고령화와 더불어 뇌졸중의 사회경제적 중요성이 커지고 있다. 미국과 국내의 통계자료를 종합하였을때, 2008 년 한해 동안 35 세에서 74 세의 인구 중약 80,500 명이 생애 첫 번째 뇌졸중으로 입원한 것으로 나타났다. 또한 35세 이상의 인구 중 뇌졸중을 않고 있는 사람이 382,000 명으로 추산되고 있다. 2009년 사망통계를 근거로 할 때, 우리나 라의 원인 별 사망률 중에서 뇌졸중은 암에 이어 두 번째 이고, 인구 100,000 명당 75.5 명이다. 이는 전체 사망 원인의 $13.9 \%$ 에 해당한다[7]. 이와 같은 뇌졸중환자들은 마비된 손 발을 버려두면 관절이 굳어버리고 무리하게 움직이면 관절을 움직일 수 없는 상태가 되기 때문이다. 근육도 위축되어 가늘 어지고 힘이 약해진다. 뼈도 위축되어 부러지기 쉬워진다[13]. 뇌졸중환자는 일상생활에서 비정상적인 근긴장도을 가지고 있으며 인지기능, 평형반응, 감정적인 반응까지 어려움을 보 인다[3]. 환측 하지로 체중지지를 거의 하지 않고, 건측으로만 체중지지를 하는 경향을 보이는데 이로 인해 건측 하지에 정 상보다 더 높은 긴장도를 형성하기도 한다. 반대로 환측 하지 에 이완성을 보일 경우 환측 하지로 체중을 이동하지 못하는 것은 무릎이 구부러지기 때문이고 부적절하게 과신전 되기도 한다. 전방움직임은 하지로부터 앞쪽방향으로 시작되며 비전 형적인 하지의 움직임은 상체가 체중이동을 시작하거나 혹은 움직임 방향이 잘못되었기 때문에 고관절굴곡과 내회전을 동 반한 골반 후방회전과 거상과 고관절 굴곡과 내전을 동반한 골반 거상이 일어난다[10]. 고관절 약화 특히 신전근과 외전근

*Corresponding author

Tel : +82-51-890-2511, Fax : +82-51-890-2643

E-mail : ywjin@deu.ac.kr
은 전방 진행 시 하지 움직임 시작을 어렵게 하며, 고관절 신전 강화와 조절은 전체 입각기의 중요한 요소이기 때문에 안전한 기능적인 보행이 요구된다[14]. 발목관절의 범위와 조절의 소 실이 나타나는데 환자는 지면에 발전체를 놓기 위해 뒤로 체 중을 이동시키고 하지의 후방움직임과 함께 발목은 저측굴곡 되고 고관절을 굴곡 시킨다. 이런 자세로부터 신체를 앞으로 움직이기 위하여 환자는 앞으로 기울이거나 혹은 건측 앞으로 회전함으로써 몸통으로 대상작용을 한다. 초기 발끝 닿기는 보행 시 전방신체 움직임의 기초로 설정되어 있는 초기 입각 기의 중요한 요소이다. 단 하지 지지기에서 고관절의 불안정 성으로 외측근육이 약하여 전방 진행시 전방보다 측면으로 더 많이 움직인다. 보행시 중력선은 슬관절 앞으로 이동하며, 과신전과 과도한 굴곡이 일어나며 이는 고관절과 발목의 정렬 과 조절문제가 직접 원인이 될 수 있다. 보행 시 몸통과 사지조 절이 균형을 유지하기 불충분할 때 발가락은 떨어지는 것을 막기 위한 신체반응의 부분으로써 바닥을 움켜잡는다. 발목관 절 배측굴곡 범위소실과 함께 종골은 내반된 자세로 움직인 다. 이러한 제한으로 발의 아치는 바뀌고 근육은 짧아진다. 양하지 지지기에서는 발뒤꿈치 떼는데 바닥 위에서 발유지의 불안정성으로 신체는 발 앞으로 움직이고 있지만 발 하지는 바닥에 접촉한 상태로 남아 있는데 골반과 고관절 근육의 경 직은 하지를 발 디딤으로 위치시키기 어렵다. 유각기에서는 비전형적인 근훙분으로 손상측 하지를 전방으로 들어 올리고 유각을 시도할 때 전방진행을 멈춘다. 전방전진 없이 보행패 턴은 정지되고 유각기는 비전형적으로 수행된다. 불충분한 발 목의 배측굴곡 발가락을 끌리지 않기 위해 몸통과 골반을 사 용한다. 내반된 발은 전족의 외측면으로 지면에 접촉한다. 이 때 신체는 발전체를 지면에 놓기 위해 후방내측으로 체중이동 이 일어난다. 이것은 전방진행의 시작에서 골반과 고관절 내 
회전을 동반한 슬관절 과신전을 초래한다. 많은 학자들은 뇌 졸중환자들을 대상으로 하퇴근육의 연구는 대부분 걷기 동작 시에 주로 사용되는 근육들을 선택하여 연구하였다 $[2,11,14]$. 지금까지 대부분의 선행연구들은 뇌졸중환자를 대상으로 단 순한 걷기동작을 통하여 하지근육의 쓰임과 운동학적 변인들 을 연구하였으며, 본 연구는 체계적인 재활운동프로그램에 참 가한 환자들을 중심으로 운동기능학 연구분야 중 각관절의 모멘트변화, 족저압력변화 그리고 하지근육의 변화를 연구하 여 뇌졸중 환자들이 안전하고 기능적인 보행을 할 수 있도록 정보제공과 재활운동의 중요성을 밝히는 데 있다.

\section{재료 및 방법}

\section{연구대상자의 특성}

본 연구의 대상자는 뇌졸중 발병 후 일정한 재활훈련 프로 그램에 참가하고 있는 왼쪽의 마비가 있는 여성 환자 7 명을 대상으로 하였으며 재활훈련 3 개월 지난 시점에서 1 차 실험을 하였고, 6 개월 지난 시점에서 2차 실험을 하였다. 연구대상자 들의 특성은 Table 1 과 같다.

\section{사용 장비}

본 연구에 사용된 분석 장비는 영상분석 장비, 족저압 분석 장비, 근전도 분석 장비 그리고 기타 장비로 구분 할 수 있으며 Table 2와 같다.

\section{실험방법 및 절차}

본 실험에 사용된 장비는 Table 2 와 같으며 영상분석, 족저 압분석 그리고 근전도 분석을 하였다. 영상분석은 걷기시 하 퇴의 움직임을 촬영하기 위하여 대상자로부터 약 $2.5 \mathrm{~m}$ 지점 좌측과 뒤쪽에 두 대의 카메라를 $90^{\circ}$ 각도로 설치하였다. 카메 라의 높이는 지면으로부터 $0.8 \mathrm{~m}$ 에 위치 시켰으며 촬영속도는 $30 \mathrm{frames} / \mathrm{sec}$ 로, 셔터 스피드는 $1 / 500 \mathrm{sec}$ 로 하였다. 뇌졸중 환자의 환측다리 첫 번째 보폭(stride length)을 촬영하여 하지
관절의 각도와 모멘트를 구하였다. 족저압측정은 런닝머신과 비슷하게 생긴 족저압분포측정기를 경사도 $0^{\circ}$ 로 고정하여 환 자의 걷기를 파악하여 속도를 조정하였다. 이때 대상자들 마 다 걷기속도가 약간의 차이는 있었지만 평균 $0.25 \pm 0.37 \mathrm{~m} / \mathrm{sec}$ 였다. 재활훈련의 시기에 따라 근육의 발달정도를 알아보기 위하여 근전도분석기를 사용하였다. 위의 3 가지 자료분석 시 동시성이 중요하기 때문에 실험장비를 동조(synchronization) 시키는 것이 요구 되었다. 대상자가 족저압분포측정기 위를 걸을 때 인위적으로 $\mathrm{LED}$ 를 점등 시켜 영상분석기와 근전도측 정기를 동조시켰다. 반사마크는 하지의 해부학적 경계점에 부 착시키고 표면전극을 환측다리의 대퇴직근(rectus femoris), 외측광근(vastus lateralis), 반건양근(semitendinosus), 비복근 (gastrocnemius) 4 가지 근육에 부착시키고 가장 편안하고 자 연스럽게 걸으라고 주문하고 런닝스피드를 조절하였다. 근육 의 활성도를 비교하기 위하여 등속성수축 테스트(isokinetic test)를 재활훈련 6개월 지나는 시점에서 실시하였는데, 각 근 육에 전극을 부착한 후 의자에 앉아서 환측의 다리를 지면과 수평 되게 최대한 앞으로 뺃어 올리게 하였다[8]. 총 3회를 실 시하여 본 연구에 합당한 자료를 선택하였다.

\section{재활 프로그램}

전문가들의 지도 아래 환자들은 일주일에 3회씩 꾸준하게 운동치료, 작업치료, 심리치료 등에 참가하였다.

\section{자료 처리 방법}

3 개월 재활트레이닝 참가와 6 개월 재활트레이닝 참가의 효 과 차이를 분석하기 위하여 통계처리는 SPSS WIN (ver. 15.0) 을 이용하여 paired t-test에 의해 계산되었다.

\section{결 과}

관절최대피크값과 모멘트값 비교

각 관절의 최대피크 값의 비교와 모멘트 값의 비교는 Fig.

Table 1. Character of subject

\begin{tabular}{cccccc}
\hline Factor & Year $(\mathrm{yr})$ & Height $(\mathrm{cm})$ & Weight $(\mathrm{kg})$ & Duration $(\mathrm{yr})$ & Injury of position \\
\hline Mean $\pm S D$ & $62.2 \pm 5.8$ & $157.2 \pm 4.1$ & $60.3 \pm 7.1$ & $5.7 \pm 2.7$ & Left \\
\hline
\end{tabular}

Table 2. Instrument

\begin{tabular}{lll}
\hline Equipment & Company & Model \\
\hline Video camera & JVC & Magic station mv40JVC \\
Zebris Emed sensor platform & Zebris Medical GmbH & GR-DVL9800 \\
Tripod & Velbon & FDM-T System \\
Illumination & LPL & Velbon VGB-36 \\
Computer & Samsung & LPL VL302 \\
EMG system & Noraxon & Telemyo 2400T G2 \\
\hline
\end{tabular}




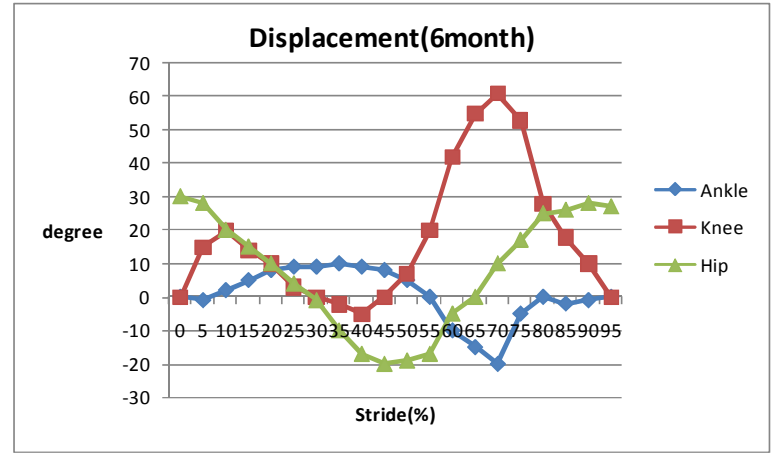

Fig. 1. Angle of joint. (+) flexion, (-) extension.

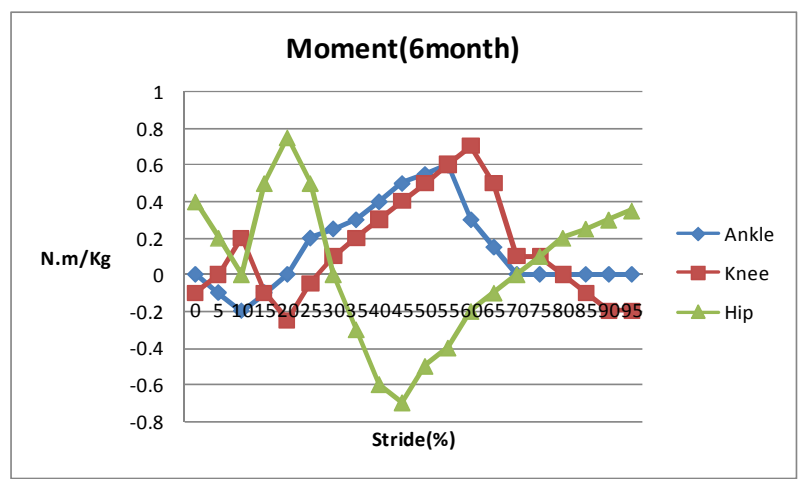

Fig. 2. Moment of joint. (+) flexion, (-) extension.

1, Fig. 2와 Table 3에서 나타난 것과 같이 발목의 최대저측굴 곡 피크 값은 통계적으로 유의한 차이는 나타나지 않았으나 평균의 비교에서 3 개월 재활트레이닝의 시점에서 $10.5 \pm 2.70^{\circ}$ 으로 나타났으며 6개월 재활의 시점에서는 $12.5 \pm 3.60^{\circ}$ 로 약간 의 차이를 보였다. 발목의 최대저측굴곡 피크와 직접적인 관 련이 있는 발목의 최대저측굴곡 피크 모멘트값의 비교는 재활 트레이닝 3 개월 지난 시점에 $0.41 \pm 0.07 \mathrm{Nm}^{\prime} / \mathrm{kg}$ 으로 나타났으 며 재활트레이닝 6 개월 지난시점에서는 $0.57 \pm 0.15 \mathrm{Nm} / \mathrm{kg}$ 으 로 나타나서 통계적으로 유의한 차이는 나타나지 않았다. 이 것은 최대저측굴곡 피크의 값과 최대저측굴곡 피크의 모멘트 와 일치하는 패턴을 보여주고 있다. 무릎최대굴곡 피크값의 비교에서는 3 개월 지난 시점에서는 $49.2 \pm 13.70^{\circ}$ 로 나타났으며
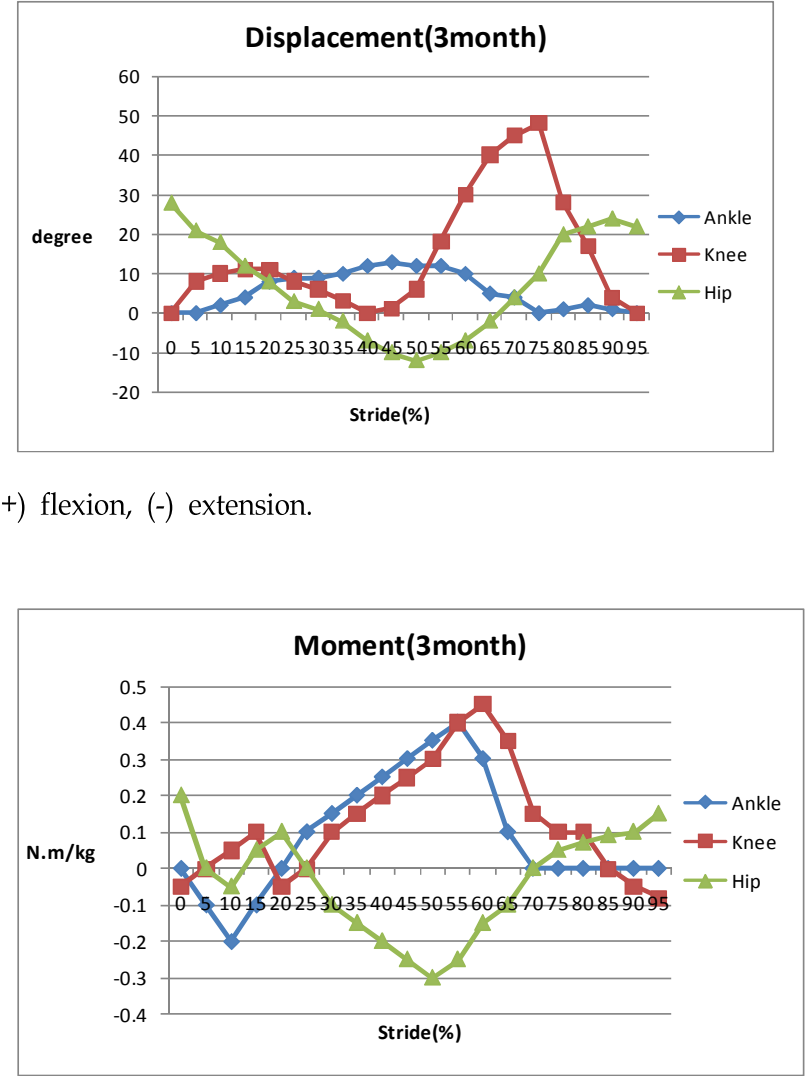

6개월 지난 시점에서는 $59.5 \pm 15.90^{\circ}$ 로 나타났다. 통계적으로 유의한 차이는 나타나지 않았다.

무릎최대굴곡 피크 모멘트의 값은 3개월 지난 시점에서 $0.47 \pm 0.15 \mathrm{Nm} / \mathrm{kg}$ 으로 나타났으며 6개월 지난 시점에서는 무 릎최대굴곡모멘트 값이 $0.69 \pm 0.82 \mathrm{Nm} / \mathrm{kg}$ 으로 나타났다. 통 계적으로 유의한 차이는 나타나지 않았지만 무릎최대굴곡 피 크 값의 형태와 비슷한 결과를 보여주고 있다.

엉덩최대신전 피크 값의 비교에서는 3개월 지난 시점에서 $-11.7 \pm 2.70^{\circ}$ 로 나타났으며 6 개월 지난 시점에서는 $-20.5 \pm 3.80^{\circ}$ 로 나타났다. 엉덩최대신전 피크 값의 비교에서는 통계적으로 유의한 차이 $(p<0.05, \mathrm{t}=2.865)$ 를 나타내었다. 엉덩최대신전 피 크 모멘트 값은 3 개월 지난 시점에서 $-0.49 \pm 0.13 \mathrm{Nm} / \mathrm{kg}$ 으로

Table 3. Angle and Moment of Joint

\begin{tabular}{|c|c|c|c|}
\hline Variable & 3 Month & 6 Month & $t$ \\
\hline Peak angle of maximum plantarflexion $\left({ }^{\circ}\right)$ & $10.5 \pm 2.70$ & $12.5 \pm 3.60$ & 0.711 \\
\hline Peak moment of maximum plantarflexion $(\mathrm{Nm} / \mathrm{kg})$ & $0.41 \pm 0.07$ & $0.57 \pm 0.15$ & 1.452 \\
\hline Peak angle of maximum knee flexion $\left({ }^{\circ}\right)$ & $49.2 \pm 13.70$ & $59.5 \pm 15.90$ & 1.512 \\
\hline Peak moment of maximum knee flexion $(\mathrm{Nm} / \mathrm{kg})$ & $0.47 \pm 0.15$ & $0.69 \pm 0.82$ & 1.693 \\
\hline Peak angle of maximum hip extension $\left({ }^{\circ}\right)$ & $-11.7 \pm 2.70$ & $-20.5 \pm 3.80$ & $2.865^{*}$ \\
\hline Peak moment of maximum hip extension $(\mathrm{Nm} / \mathrm{kg})$ & $-0.49 \pm 0.13$ & $-0.71 \pm 0.21$ & $2.520^{*}$ \\
\hline
\end{tabular}

${ }^{*} p<0.05, \mathrm{df}=6, t=2.431,(-)$ direction of watch 
나타났으며 6개월 지난 시점에서는 $-0.71 \pm 0.21 \mathrm{Nm} / \mathrm{kg}$ 으로 나 타났다. 통계적으로 유의한 차이 $(p<0.05, \mathrm{t}=2.520)$ 를 나타내었 다. 이것은 엉덩최대신전 피크 값의 통계적 차이를 뒷받침하 는 결과로 사료된다.

\section{족저압 비교}

재활트레이닝의 3개월 시점과 6개월 시점에서 실험한 족저 압의 비교는 Fig. 3 과 Table 4에 나타난 것과 같이 걷기 동작시 오른발과 왼발의 압력중심의 변화를 나타내는 선의 길이(gait line length)는 건측발인 오른쪽에서는 $133.2 \pm 21.1 \mathrm{~mm}$ 와 $165.9 \pm 31.8 \mathrm{~mm}$ 로 나타났으며 통게적인 유의한 차이는 없었 다. 환측발인 왼쪽에서는 $85.5 \pm 10.2 \mathrm{~mm}$ 와 $127.6 \pm 16.9 \mathrm{~mm}$ 로 나타났으며 통계적으로 유의한 차이 $(p<0.05, \mathrm{t}=2.541)$ 를 나타 내었다. 걷기 동작 중에 한발이 완전히 지지한 상태(single support line)를 나타내는 비교에서는 건측발인 오른쪽(74.1 $8.3 \mathrm{~mm}, 94.9 \pm 14.3 \mathrm{~mm})$ 과 환측발인 왼쪽 $(49.2 \pm 7.4 \mathrm{~mm}, 62.5 \pm$ $11.7 \mathrm{~mm}$ )에서 통계적으로 유의한 차이를 나타내지 않았다.

Fig. 3 에 나타난 걷기 동작 시 발바닥 압력중심선의 좌우의 변화를 동시에 나타내는 나비모양(butterfly parameter)의 교 차점이 양발의 중심으로부터 벗어난 위치를 나타내 주는 값 (lateral symmetry)의 변화는 $-5.3 \pm 3.9 \mathrm{~mm},-3.6 \pm 2.5 \mathrm{~mm}$ 로 나 타났으며 통계적으로 유의한 차이는 나타나지 않았다. 양발의 중심으로부터 벗어난 위치를 나타내주는 값의 편차를 나타낸 값(lateral variability)의 비교에서는 통계적으로 유의한 차이 를 나타내지 않았지만 평균의 비교 $(5.6 \pm 2.7 \mathrm{~mm}, 4.3 \pm 2.1 \mathrm{~mm})$ 에서는 약간의 차이를 보였다.

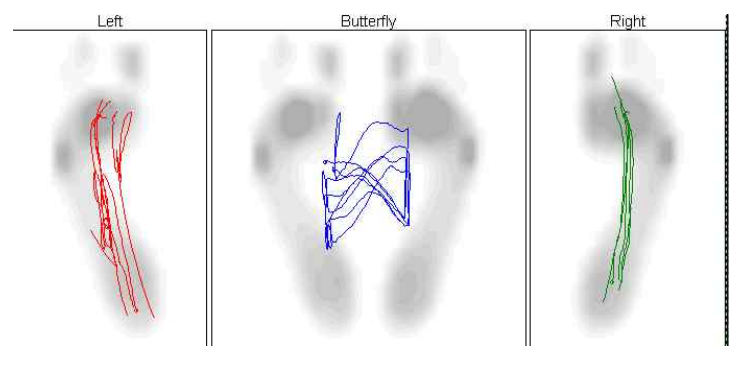

3 month

\section{근전도 변화}

문헌연구를 통하여 걷기동작에 영향을 미치는 하퇴의 주요 근육 4 가지를 선택하여 근전도분석을 실시한 결과 Fig. 4 는 걷기동작 동안 대표적인 한 사람의 약 10 초간의 환측다리의 근전도분석 값이며, Table 5 는 영상분석과 동조를 생각하여 환측 다리가 1 보폭을 움직이는 동안 최대값을 선택하여 평균 과 표준편차를 나타낸 것이다. 환측다리의 등속성수축시 최대 값을 기준으로 하여 각 근육을 비교하였다. 대퇴직근은 재활 훈련 3개월 참가시에 $7.05 \pm 12.8 \%$ 로 나타났으며 6개월 참가시 에는 $32.95 \pm 15.51 \%$ 로 나타나서 통계적으로 유의한 차이를 보 였다 $(p<0.05, \mathrm{t}=2.871)$.

외측광근은 재활훈련 3 개월 참가시에 $13.42 \pm 9.64 \%$ 로 나타 났으며 6 개월 참가시에는 $47.32 \pm 17.10 \%$ 로 나타나서 외측광근 또한 통계적으로 유의한 차이를 나타내었다 $(p<0.05, \mathrm{t}=2.972)$. 반건양근은 3 개월 참가시에 $78.51 \pm 11.49 \%$ 로 나타났으며 6 개 월 참가시에 $84.29 \pm 13.52 \%$ 로 나타났으나 통계적으로 유의한 차이는 나타나지 않았지만 평균의 비교에서는 약간의 차이를 보였다 $(p<0.05, \mathrm{t}=1.052)$.

비복근의 비교에서는 3 개월 참가시에 $92.79 \pm 8.30 \%$ 로 나타 났으며 6개월 참가시에 $95.63 \pm 10.35 \%$ 로 나타났다. 통계적으로 차이를 나타내지 않았다 $(p<0.05, \mathrm{t}=0.948)$.

\section{고 찰}

본 연구는 정상적인 재활훈련에 참가하는 뇌졸중환자를 대 상으로 3 개월 지난시점과 6 개월 지난 시점에서 재활훈련의

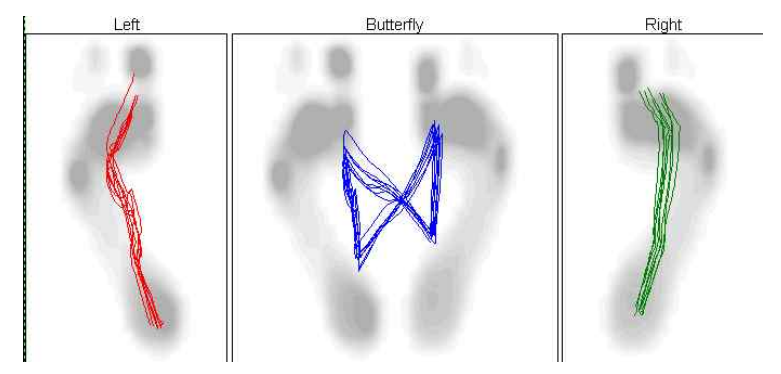

6 month

Fig. 3. Pressure of butterfly shape.

Table 4. Comparison of pressure

(unit: $\mathrm{mm}$ )

\begin{tabular}{|c|c|c|c|c|c|}
\hline \multirow[b]{2}{*}{ Variable } & \multicolumn{2}{|c|}{3 Month } & \multicolumn{2}{|c|}{6 Month } & \multirow[b]{2}{*}{$t$} \\
\hline & Right & Left & Right & Left & \\
\hline Gait line length & $133.2 \pm 21.1$ & $85.5 \pm 10.2$ & $165.9 \pm 31.8$ & $127.6 \pm 16.9$ & $1.591,2.541^{*}$ \\
\hline Single support line & $74.1 \pm 8.3$ & $49.2 \pm 7.4$ & $94.9 \pm 14.3$ & $62.5 \pm 11.7$ & $1.651,1.770$ \\
\hline Lateral symmetry & \multicolumn{2}{|c|}{$-5.3 \pm 3.9$} & \multicolumn{2}{|c|}{$-3.6 \pm 2.5$} & 0.915 \\
\hline Lateral variability & \multicolumn{2}{|c|}{$5.6 \pm 2.7$} & \multicolumn{2}{|c|}{$4.3 \pm 2.1$} & 0.671 \\
\hline
\end{tabular}

${ }^{*} p<0.05, \mathrm{df}=6, t=2.431,(-)$ direction of left 


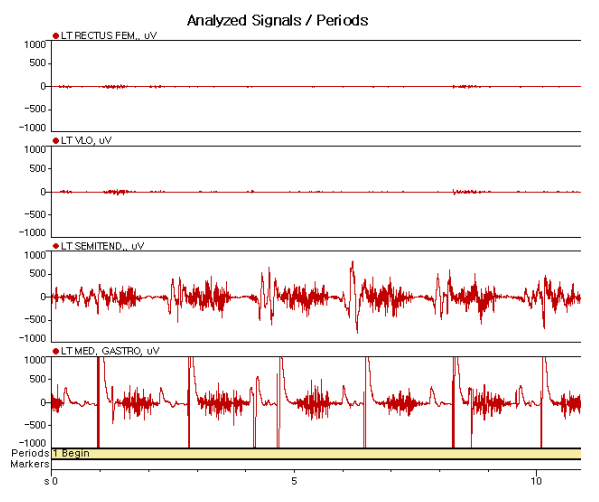

3 month

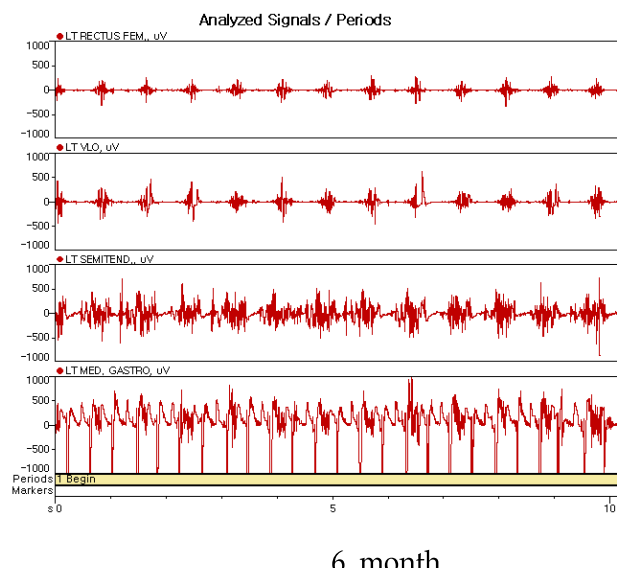

6 month

Fig. 4. Comparison of EMG

Table 5. EMG of lower limb

\begin{tabular}{|c|c|c|c|c|}
\hline Muscle $\quad$ Month & Isokinetic contraction $(100 \%)$ & 3 Month & 6 Month & $t$ \\
\hline Rectus femoris (\%RVC) & 100 & $7.05 \pm 12.8$ & $32.95 \pm 15.51$ & $2.871^{*}$ \\
\hline Vastus lateralis (\%RVC) & 100 & $13.42 \pm 9.64$ & $47.32 \pm 17.10$ & $2.972^{*}$ \\
\hline Semitendinosus (\%RVC) & 100 & $78.51 \pm 11.49$ & $84.29 \pm 13.52$ & 1.052 \\
\hline Gastrocnemius (\%RVC) & 100 & $92.79 \pm 8.30$ & $95.63 \pm 10.35$ & 0.948 \\
\hline
\end{tabular}

${ }^{*} p<0.05, \mathrm{df}=6, t=2.431$

결과를 운동역학적으로 비교분석하기 위하여 실험 하였다. 보 행 동작시 각관절의 움직임을 살펴 본 결과 발목관절의 저측 굴곡은 약 $2^{\circ}$ 의 차이를 보였는데 이것은 지속적으로 재활훈련 에 참가한 결과 바닥을 더욱 자신 있게 밀면서 걸음걸이를 하는 동작으로 나타났다. Jin [4]의 재활운동에 참가한 뇌졸중 환자들의 걷기 형태 비교연구에서 보폭의 길이가 늘어나고 보폭의 시간이 줄어들었다는 연구 결과와 일치하는 것으로 나타났다. 뇌졸중환자들의 걷기동작시에 발의 변형에 관한 발 표를 한 연구에서는 남자들을 대상으로 약간의 걷기 속도가 다르기는 하였으나 배측굴곡의 최대피크 값은 $18.25^{\circ}$ 였고 저 측굴곡의 최대피크 값은 $15.42^{\circ}$ 로 나타났다고 보고하였다[12]. 이것은 걷기 동작시에 전체적인 발목관절의 저측굴곡 값의 변화 형태는 본 연구와 비슷한 결과를 나타내었다. 뇌졸중 환 자를 대상으로 $0.45 \pm 0.25 \mathrm{~m} / \mathrm{sec}$ 와 $0.59 \pm 0.34 \mathrm{~m} / \mathrm{sec}$ 의 속도로 걷기속도를 달리한 연구에서 $17.7 \pm 5.1^{\circ}$ 와 $24.6 \pm 8.0^{\circ}$ 로 많은 차 이를 보였다[5]. 저측굴곡 값에서 상당한 차이를 보였는데, 이 들의 연구에서는 남자를 대상으로 하여 보폭과 걸음걸이 빈도 수에서 상당한 차이를 나타내었다. 발목 최대 저측굴곡시 모 멘트값은 통계적으로 유의한 차이를 나타내지는 않았지만 평 균값에서는 상당한 차이를 보이고 있다. 이것은 발목최대굴곡 피크 값의 차이를 나타내 주는 원인으로 파악된다. 뇌졸중환 자들의 걷기 동작시에 발의 변형에 관한 발표를 한 연구에서 는 정상인 60 세 전후의 남자 대상자들은 $1.10 \pm 0.25 \mathrm{Nm} / \mathrm{kg}$ 으
로 나타난 모멘트 값과는 많은 차이를 보이고 있다[12]. 재활훈 련기간이 길어지면서 발목관절의 회전모멘트가 커지고 있는 것을 볼 수 있다. 재활운동에 참가하는 뇌졸중환자를 대상으 로 근육활동의 변화에 대한 컴퓨터 모델링 연구에서 요구된 발목관절의 모멘트 값의 변화는 실제 재활훈련을 통하여 거의 제시된 값에 근접하게 나타난다고 보고하였다[11]. 위와 같은 선행연구와 본 연구를 통하여 얻은 결론은 발목관절의 각도변 화에 영향을 미치는 모멘트 값의 변화는 재활훈련을 통하여 많은 향상을 가져온다는 사실을 증명 하였다. 무릎관절의 최 대굴곡피크 값은 재활훈련 기간이 길어지면서 약 $10^{\circ}$ 의 차이 를 보이고 있다. 재활훈련에 꾸준하게 참가하면서 자신 있게 무릎을 펴는 것으로 사료된다. 재활운동에 참가한 뇌졸중환자 들의 걷기 형태 비교연구에서 시상면에서 나타난 무릎의 최대 굴곡 값은 $59.5^{\circ}$ 와 $57.8^{\circ}$ 로 나타났다고 보고한 결과와 거의 비 슷한 값을 나타내었다[4]. 뇌졸중 환자를 대상으로 $0.45 \pm 0.25$ $\mathrm{m} / \mathrm{sec}$ 와 $0.59 \pm 0.34 \mathrm{~m} / \mathrm{sec}$ 의 속도로 걷기속도를 달리한 연구 에서 $33.7 \pm 21.3^{\circ}$ 와 $49.8 \pm 8.0^{\circ}$ 로 많은 차이를 보였다[5]. 이러한 차이는 속도를 다르게 연구한 결과로 생각되며 대상자들의 속도 콘트롤에 상당한 어려움을 가진 실험 이었다. 무릎관절 의 최대굴곡 피크 모멘트의 값은 두가지 실험상황에서 통계적 으로 유의한 차이는 나타나지 않았지만 무릎굴곡각도의 차이 와 같이 모멘트의 값도 상당한 차이를 보여 걷기 동작시 무릎 회전각도의 변화에 영향을 미치는 것으로 나타났다. 정상인 
노인과 뇌졸중환자를 대상으로 앉았다가 일어나는 동작과 앉 는 동작의 근력 비교연구에서 무릎관절의 신전모멘트는 정상 인은 $0.71 \mathrm{Nm} / \mathrm{kg}$ 으로 나타났으며 뇌졸중환자는 $0.42 \mathrm{Nm} / \mathrm{kg}$ 으로 나타났다고 보고하였으며, 굴곡 동작시 무릎관절의 모멘 트는 정상인은 $0.43 \mathrm{Nm} / \mathrm{kg}$ 으로 나타났으며 뇌졸중환자는 $0.25 \mathrm{Nm} / \mathrm{kg}$ 으로 나타내었다고 발표하였다[6]. 이러한 결과는 본 연구와는 다소 차이를 보이는 값으로 걷기동작과 앉기-서 기 동작과는 차이가 있는 것으로 생각된다. 본 실험을 통하여 환자들을 눈으로 관찰한 결과도 3 개월 재활훈련 참가자 보다 6개월 훈련 참가자가 훨씬 힘차게 무릎을 펴는 것을 볼 수 있었다. 엉덩최대신전 피크 값에서는 통계적으로 유의한 차이 가 나타났다. 이것은 환자들이 걷기 동작시에 하지를 정상인 과 같이 부드럽게 걷지를 못하고 환측다리를 들어서 돌리는 동작으로 보행을 하고 있어서 재활훈련기간이 3개월 보다는 6개월 동안 꾸준하게 참여하여 엉덩관절 주위의 근력이 강화 되어 관절을 더욱 자신 있게 펴는 것으로 생각된다. 뇌졸중환 자와 정상인을 대상으로 걷기속도를 달리한 연구에서 정상인 의 최대 엉덩관절신전 피크 값은 $41.1 \pm 81^{\circ}$ 로 나타났으며 뇌졸 중환자의 최대 엉덩관절 신전 피크 값은 $34.6 \pm 19.1^{\circ}$ 로 나타났 다[5]. 뇌졸중환자의 값은 본 연구와는 상당한 차이를 보이고 있다. 이것은 재활훈련 기간의 차이와 걷기속도의 차이로 생 각된다. 엉덩최대신전 피크 모멘트의 값은 통계적으로 유의한 차이를 나타내었다. 이것은 엉덩최대신전 피크 값의 결과와 일치하는 것으로 나타났다. 뇌졸중환자를 대상으로 걷기속도 를 달리하여 정상인과 뇌졸중환자를 대상으로 한 연구에서 엉덩관절 신전최대 피크 모멘트의 값은 정상인 $0.60 \pm 0.25$ $\mathrm{Nm} / \mathrm{kg}$ 으로 나타났으며, 뇌졸중환자는 $0.33 \pm 0.17 \mathrm{Nm} / \mathrm{kg}$ 으 로 나타났다고 보고 하였다[5]. 족저압의 비교에서는 걷기 동 작시 오른발과 왼발의 압력중심의 변화를 나타내는 선의 길이 는 건측발인 오른쪽에서는 통계적으로 유의한 차이를 나타내 지 않았으나 환측발인 왼쪽 발에서는 통계적으로 유의한 차이 를 나타내었다. 이것은 재활훈련에 꾸준히 지속적으로 오랜기 간 참가한 대상자들의 관절 모멘트 값의 변화와 같이 근력들 의 강화로 인하여 걸음걸이가 자신 있게 변화되는 결과로 나 타났다. Oh와 Lee [9]의 신발의 족저압 연구에서 좋은 신발은 걷기 동작시 지지(heel strike) 구간에서 발생하는 충격량을 감 소시켜 장시간 보행시 발의 피로도를 줄이는 역할을 한다고 발표하였다. 본 연구에서 뇌졸중환자들의 대부분은 환측발의 최초지면 접촉시 족저압 변화를 보면 상당한 충격을 주는 것 으로 나타났다. 총격을 완화해주는 보조물의 착용을 고려하는 것도 신체에 전달되는 충격량을 경감시켜 하지관절에 발생하 는 부하를 줄여주는 중요한 요인으로 생각된다. 한발을 완전 히 지지한 상태에서는 건측과 환측 모두 통계적으로 유의한 차이를 나타내지 않았다. 양발의 좌우변화를 나타내는 압력중 심선의 나비모양의 교차점은 좌우로 약간 벗어나는 변화를 보였으며, 좌우로 벗어난 편차를 나타내 주는 값에서도 재활
훈련의 기간에 따른 통계적 차이는 나타나지 않았다. 압력중 심선의 좌우변화는 재활훈련의 기간의 변화와는 크게 차이가 없는 것으로 나타났다. 뇌졸중환자를 대상으로 서서 균형잡기 연구에서 좌우균형 감각은 재활훈련 전에는 압력중심선의 좌 우 변화가 -59 mm로 부터 $20 \mathrm{~mm}$ 까지 변화가 있었으나 재활 훈련 후에는 좌우변화가 $-40 \mathrm{~mm}$ 로부터 $22 \mathrm{~mm}$ 로 나타나서 많은 변화가 없다고 보고하였다[1]. 이것은 본 연구와 일치하 는 결과로 나타났다. 하퇴근육의 비교는 문헌연구 $[2,11,14]$ 를 통하여 뇌졸중환자들의 걷기 동작시에 주로 많이 쓰이는 근육 을 선택하여 연구 하였다. 대퇴사두근 중에서 대퇴직근과 외 측광근의 비교에서 통계적으로 유의한 차이를 나타내었다. 이 것은 엉덩관절의 피크 모멘트 값의 연구결과와 일치하는 것으 로 재활훈련은 대퇴근력을 향상시키는데 큰 도움이 되는 것으 로 나타났다. 햄스트링중에서 반건양근의 역할은 걷기동작에 많은 영향을 미치는 것으로 선행연구에서 보고 되었으나 본 연구에서는 통계적으로 유의한 차이는 나타나지 않았으나 평 균의 비교에 약간의 차이를 보였다. 무릎관절과 발목관절에 영향을 미치는 비복근의 연구에서는 통계적으로 유의한 차이 를 나타내지 않았다. 뇌졸중환자의 걷기동작을 3 가지 축을 가 진 가속도계와 근력분석기를 사용하여 분석한 연구에서 세가 지축의 근력의 변화는 재활훈련의 기간에 따라 근력이 상대적 으로 좋아지는 근육도 있었지만 그렇지 못한 근육도 있었다고 보고 하였다[2]. 이것은 본 연구와 일치하는 것으로 나타났다. 뇌졸중환자를 대상으로 근육활동의 올바른 변화를 평가하기 위하여 역학적인 모델의 연구에서 각관절의 관절모멘트 값을 높이기 위해서 관절 주위 근육들의 세밀한 연구가 있어야 한 다고 주장하였다[11]. 뇌졸중환자 재활훈련중에 근전도분석과 운동역학적분석에서 관절의 신전과 굴곡의 변화에 따라 예민 하게 근력의 변화가 일어나는데 이것은 관절모멘트와 관절힘 의 예민한 변화를 뒷받침하는 증거라고 발표하였다[14]. 여러 연구들에서 제시된 것과 같이 관절주위의 근력을 키우기 위해 서는 세밀한 근력 재활훈련이 필요한 것으로 생각된다.

\section{결과 및 고찰}

재활훈련에 참가하는 뇌졸중환자를 대상으로 3 개월 지난 시점에서 1 차 실험을 하였고 6 개월 지난 시점에서 2 차 실험을 하였다. 영상분석결과 발목관절과 무릎관절의 각도변화와 모 멘트변화는 통계적으로 유의한 차이를 나타내지 않았으나 엉 덩관절의 각도변화와 모멘트변화는 통계적으로 유의한 차이 를 나타내었다. 이것은 환측 다리의 움직임에 엉 덩관절이 많 이 관여하는 것으로 사료되며 엉덩관절 주위의 근력강화훈련 을 꾸준하게 해야 할 필요성을 제시해준다. 족저압 분석기를 통하여 발바닥의 압력중심선의 변화를 분석한 결과는 압력중 심선의 좌우변화는 통계적으로 유의한 차이를 나타내 않았으 나 일반적인 걷기 동작시에 환측발의 압력중심선의 변화는 
재활훈련기간이 길어지면서 더욱더 정상인과 거의 비슷한 발 뒷꿈치에서 발가락으로 힘이 전달되는 걸음걸이(heel-toe walking)를 하는 것으로 나타났다. 근전도 분석에서는 대퇴사 두근의 변화가 통계적으로 유의한 차이를 나타내었다. 이것은 엉덩관절 최대 피크 모멘트 값의 변화에 영향을 주는 좋은 증거로 생각된다. 본 연구를 진행하면서 비슷한 환자들을 모 으기에 힘이 들었으며, 걷기속도를 통제하는데 많은 어려움이 있었다. 재활훈련 기간이 1 년이 지난 후에 3 차 실험을 하여 비교분석하는 것도 좋은 연구가 되리라고 생각된다.

\section{감사의 글}

이 논문은 2009학년도 동의대학교 교내연구비에 의해 연구 되었음(2009AA228).

\section{References}

1. Alexander, C. H., H. Mirjam, J. W. Ilse, and J. Duysens. 2005. A review of standing balance recovery from stroke. Gait Posture 22, 267-281.

2. Chihiro, M., O. Shohei, and S. Morita. 2009. Analysis of stroke patient walking dynamics using a tri-axial accelerometer. Gait Posture 30, 60-64.

3. Hochstenbach, J., R. Donders, T. Mulder, J. van Limbeek, and H. Schoonderwaldt. 1996. Long-term outcome after stroke. a disability-orientated approach. Int. J. Rehabil. Res. $19,189-200$

4. Jin, Y. W. 2009. The comparison research on walking pattern of rehabilitation training program participants in stroke patients. J. Life Sci. 19, 1299-1303.

5. Maria, C. K. and J. E. Janice. 2004. Magnitude and pattern of 3D kinematic and kinetic gait profiles on persons with stroke: relationship to walking speed. Gait Posture 24, 140-146.

6. Melanie, J. L. and J. E. Janice. 2005. Muscle strength and weight-bearing symmetry relate to sit-to-stand . performance in individuals with stroke. Gait Posture 22, 126-131.

7. Statistics Korea. http://kr.blog.yahoo.com/jjcury/1469.

8. Nihat, O. and N. Margareta. 1991. Fundamentals of Biomechanics. pp. 99-102, 1th eds., Springer-verlag. New York.

9. Oh, Y. J. and C. M. Lee. 2009. Research of 3-axis impulse acceleration of lower limb joint at walking. J. Ergonomics Society 28, 33-39.

10. Robert, C., P. H. John, and R. N. Charles. 1992. Human Anatomy and Physiology. pp. 310-311, 2th eds., New Jersey.

11. Shao, Q. and S. B. Thomas. 2008. A biomechanical model to estimate corrective changes in muscle activation patterns for stroke patients. J. Biomechanics 41, 3097-3100.

12. Sharon, K. and K. Moran. 2008. Gait pattern categorization of stroke participants with equinus deformity of the foot. Gait Posture 27, 144-151.

13. Shin, H. D. 1999. The win of stroke patient. pp. 29-32, 1th eds. Seoul.

14. Susan, J. H. 2003. Basic Biomechanics. pp. 232-235, 4th eds., McGraw Hill. New York.

15. Wolf, S. L., A. J. Bulter, J. L. Alberts, and M. W. Kim. 2005. Contemporary linkages between EMG, kinetics and stroke rehabilitation. J. Electromyog. Kinesiol. 15, 229-239.

\section{초록 : 재활운동에 참가한 뇌졸중환자의 운동과학적 연구}

\section{진 영 완ㅊ}

(동의대학교 특수체육학과)

본 연구는 뇌졸중 발병 후 재활운동에 참가하는 환자들을 대상으로 재활운동 3 개월이 지난 시점에서 1 차 실험 을 하였고, 6 개월이 지난 시점에서 2 차 실험을 하여 운동역학적 비교분석을 하였다. 실험에 사용된 장비는 영상분 석기, 족저압분석기, 근전도분석기를 사용하였다. 대상자는 7명으로 하였으며 통계방법은 t-test분석 이용하였다. 결과는 엉덩관절의 최대신전 피크 값과 최대신전 피크 모멘트 값에서 통계적으로 유의한 차이를 나타내었다 $(p \times 0.05)$. 족저압의 비교에서는 환측 다리의 족저압에서 일반적인 걷기 동작시에 족저압의 중심이동거리에서 통 계적으로 유의한 차이를 나타내었다( $p \times 0.05)$. 근전도 분석에서는 대퇴사두근 중의 대퇴직근과 외측광근의 근력에 서 통계적으로 유의한 차이를 나타내었다( $p<0.05)$. 